\title{
Customer Equity Drivers and Future Sales
}

Research on linking operational marketing inputs to customer attitudes and customer behavior has been gaining significance concomitant with the growing recognition that customers are market-based assets. In response to this, researchers and practitioners have proposed several conceptual models. Despite recent advances in research, the results are still inconclusive as to the relationship between customer attitude and future sales. A reason for this could be due to the paucity of studies combining survey-based data with behavioral data to understand better the drivers of customer behavior. With that in mind, the authors investigate the effects of customer perceptions of key marketing actions on customer attitudes and actual customer behavior as reflected by future sales. The authors propose that customer perceptions of value, brand, and relationship_-customer equity drivers"-affect loyalty intentions and future sales. The results of the study, which is based on a sample of 5694 customers of a large European do-it-yourself retailer, suggest that customer equity drivers can significantly predict future sales, even after the authors control for the current sales level.

Keywords: customer equity, brand, relationship, loyalty, retailing

0 enior managers faced with the day-to-day challenges of increasing performance of their products and services seem to spend millions of dollars on marketing programs without knowing whether their investments produce reasonable returns. It is possible that managers simply do not know how or are not able to calculate the return on investment for their marketing programs. They lack a model that links marketing actions with customer spending actions and instead are often left to use intuition to make decisions. The customer equity model (Rust, Zeithaml, and Lemon 2000) was one of the first methods with potential to forge this missing link. The concept of customer equity brings together customer value management, brand management, and relationship/retention management. It is viewed as the basis for a new strategic framework from which to build more powerful, customer-centered marketing programs that are financially accountable and measurable (Lemon, Rust, and Zeithaml 2001).

In the current competitive marketing environment, customer equity as a measure of the expected future behavior of a firm's customers is a key strategic asset that must be monitored and nurtured by firms to maximize long-term performance. Given the advantages that accrue to a company with high customer equity, effective management

Verena Vogel is a consultant, Bayer Business Services GmbH (e-mail: verenavogel@yahoo.de). Heiner Evanschitzky is Professor of Marketing, Department of Marketing, University of Strathclyde (e-mail: evanschitzky@strath.ac.uk). B. Ramaseshan is Professor of Marketing and Head of the School of Marketing, Curtin University of Technology (e-mail: ramaseshanb@cbs.curtin.edu.au). The authors thank Alexander Eiting, Florian von Wangenheim, David Woisetschläger, and Markus Wübben as well as the four anonymous JM reviewers for their constructive comments on previous versions of this article. They express special thanks to the International Center for Franchising and Cooperation, Muenster, Germany, and its head, Dieter Ahlert. requires careful monitoring of customer equity both to detect signals of erosion in customer equity and to appropriate programs to enhance it. With the growing recognition that customers are market-based assets, research on linking operational marketing inputs to customer attitudes and customer equity has been gaining significance. In response to this, several conceptual models have been proposed (Bolton, Lemon, and Verhoef 2004; Kamakura et al. 2002; Reinartz and Kumar 2000; Rust, Lemon, and Zeithaml 2004). However, despite the recent advances in research, the results are still inconclusive as to the relationship among marketing inputs, customer attitudes, and customer behavior (Villanueva and Hanssens 2007).

Bolton, Lemon, and Verhoef (2004) link instrumental marketing inputs to customer perceptions, customer behavior, and financial outcomes. Similarly, Verhoef (2003) links customer relationship perceptions and relationship marketing instruments to customer behavior. Rust, Zeithaml, and Lemon (2000) and Rust, Lemon, and Zeithaml (2004) propose a comprehensive model that identifies different drivers of a company's outcomes. They suggest a customer value model, stating that three equity drivers - value equity, brand equity, and relationship equity-influence a customer's switching matrix, which in turn has an impact on customer lifetime value (CLV) and customer equity. Although Rust and colleagues' model attempts to connect research on brand equity and customer equity, it does not fully integrate the loyalty concept.

Reinartz and Kumar's (2000), Rust, Zeithaml, and Lemon's (2000), and Rust, Lemon, and Zeithaml's (2004) models use CLV to measure firms' financial outcomes. Customer lifetime value is a valuable marketing metric, but though estimating and managing it adequately is a worthwhile ambition, it remains a pipe dream for most companies. Thus far, research in this area has essentially relied on attitudinal survey data to calculate customer value. How- 
ever, self-reported share of wallet is not as useful as real purchase data to measure customer behavior and customer value (Keiningham, Perkins-Munn, and Evans 2003).

This article contributes to the customer equity literature in the following ways: First, the proposed model includes the construct of loyalty instead of a switching matrix. The model tries to respond to one key concern of Rust, Zeithaml, and Lemon's (2000) model; that is, they did not consider the concept of loyalty.

Second, given that CLV is a difficult concept to measure and is outside the limits of most companies (Stahl, Matzler, and Hinterhuber 2003), we do not attempt to explain the drivers of CLV but rather focus on the drivers of "future sales." In reality, few companies can accurately measure CLV, which makes it virtually impossible to manage properly. The barriers have to do with the ways companies are organized, make decisions, and track information. To circumvent these hurdles, we use actual sales from each customer as the intrinsic value of customers (i.e., the accumulated and discounted sales of the customers during the six-month period after having assessed their perceptions and attitudes). Although these data are not connected as directly to customer equity as CLV, they nevertheless can provide powerful insights and help management make more efficient and more customer-focused decisions. Moreover, these data are much more readily available to companies.

Third, it is important to predict changes in consumer behavior that are driven by marketing actions and not by consumers habitually buying at the same store as a result of inertia effects (Bronnenberg and Wathieu 1996; Corstjens and Lal 2000). We control for such consumer inertia by including past sales as predictors as well.

Fourth, this study is unique in its approach to combining survey data with real purchase data. Seiders and colleagues (2005) point out that behavioral data are more accurate in evaluating the effectiveness of a firm's marketing strategy. They suggest that purchase data represent an important complement to customer self-reported data, such as a selfreported behavioral loyalty measure (e.g., share of wallet). Thus, we measure past sales using loyalty card data and link them with future sales to examine the effects of the three equity drivers_-value equity, brand equity, and relationship equity—on a consumer's loyalty and his or her future purchase behavior. By doing so, we also eliminate the concerns of common method variance, simultaneity, and endogeneity (Seiders et al. 2005).

To recapitulate, our focus on the drivers of future sales reflects more clearly what we really try to show as our main contribution. We provide the statistical and implementation details necessary to employ the customer equity framework in practice. Furthermore, we demonstrate that the customer equity drivers that Rust, Zeithaml, and Lemon (2000) identify can significantly predict future sales, even after we control for the current sales level. That means that apart from the well-known inertia effect, we identify drivers of future sales.

We organize the remainder of this article as follows: We begin by briefly describing Rust, Zeithaml, and Lemon's (2000) model as our conceptual starting point. Then, we extend the model by introducing the concept of loyalty and derive hypotheses about the possible relationships between the different parts of the model. With three-stage least squares (3SLS) regression analysis, we test five hypotheses using survey data and purchase data from a sample of 5694 customers of a large European do-it-yourself retailer. We conclude by outlining managerial implications and possible directions for further research.

\section{Literature}

One of the first attempts to link marketing inputs to customers' reactions was Rust, Zeithaml, and Lemon's (2000) model. The authors proposed that marketing inputs affect customer preferences and, thus, choice probability for a particular brand. In turn, choice probability influences customer value, which is a base to determine the customer equity of a company. The model views value equity, brand equity, and relationship equity as strategic investment categories that ultimately influence customer equity (see also Rust, Lemon, and Zeithaml 2004).

Value equity is the customers' objective assessment of the utility of a brand based on perceptions of what is given up for what is received. Brand equity is more subjective and emotional. It is the intangible assessment of a brand, beyond its objectively perceived value. Finally, the model includes relationship equity, which expresses the tendency of customers to stay in a relationship with the brand, beyond objective and subjective assessments of the brand. These three drivers are expected to influence the customers' brand-switching behavior, as displayed in a Markov switching matrix. This matrix is the basis for the calculation of an individual customer's lifetime value. In line with Blattberg and Deighton (1996), the individual CLVs are summed up to form the company's customer equity.

A major strength of Rust, Zeithaml, and Lemon's (2000) model is its ability to relate a company's perceived marketing strategy and marketing investments to the customers' reactions to these investments and to the economic output generated by the related customer behavior. Thus, it helps improve the budget allocation of the marketing spending (see also Rust, Lemon, and Zeithaml 2004). Furthermore, the model is one of the first attempts to connect the two research streams on brand equity and customer equity.

However, the model does not consider some key aspects of customer loyalty. By including the construct of loyalty intentions (e.g., as suggested by Oliver 1997) instead of a switching matrix, it is possible to address a core criticism of Markov models - that is, the assumption of constant payments or sales over time (Armstrong and Farley 1969; Ehrenberg 1965; Rust, Lemon, and Zeithaml 2004). Rust, Zeithaml, and Lemon (2000) use survey data to calculate CLV and customer equity. The use of self-reported share of wallet might be a good indicator of CLV in the absence of real purchase data. However, it is beneficial to combine survey data (to measure perceptions of marketing actions and attitudes) and purchase data (to assess future sales) to validate the model.

To summarize, our model tries to address two particularly important concerns of Rust, Zeithaml, and Lemon's (2000) model: (1) not considering the concept of loyalty 
and (2) not using behavioral data. We do this by including observed purchase behavior and, in particular, the loyalty construct, in line with Bolton, Lemon, and Verhoef's (2004), Kumar, Lemon, and Parasuraman's (2006), and Verhoef's (2003) conceptual suggestions. Thus, our model is well suited to improve the understanding of the relationship among perceived marketing actions, customer attitudes, and future sales. In the following section, we derive hypotheses that are related to the influence of value equity, brand equity, and relationship equity on loyalty intentions as well as the impact of loyalty intentions and past sales on future sales.

\section{Development of Hypotheses}

\section{Drivers of Loyalty Intentions}

Loyalty intentions can be viewed as a customer's psychological disposition toward an object. In a purchase situation, loyalty intentions reflect favorable attitudes toward the brand or firm (Dick and Basu 1994). The drivers of loyalty are complex and dynamic, and they change and evolve over time (Johnson, Hermann, and Huber 2006). Several specific psychological antecedents motivate loyalty. Consistent with Taylor, Hunter, and Longfellow (2006), marketing models trying to explain the evolution of loyalty need to consider not only cognitive aspects but also affective aspects.

Value equity. Value equity, the first driver of loyalty intentions, can be understood as the perceived ratio of what is received (e.g., a product) to what must be sacrificed (e.g., the price paid for the product). Thus, a favorable pricequality ratio is indicative of high value equity. If a customer's outcome-input ratio corresponds to his or her own reference outcome-input ratio, the experience of inner fairness results (Oliver and DeSarbo 1988). Equity theory maintains that perceived equity produces positive affective states that lead to positive attitudes, such as satisfaction and loyalty (Adams 1965; Homans 1961; Walster, Walster, and Berscheid 1978). This theoretical reasoning is largely supported by empirical studies (e.g., Lam et al. 2004; Silvestro and Cross 2000; Yang and Peterson 2004; Zins 2001). Furthermore, Rust, Zeithaml, and Lemon (2000) and Rust, Lemon, and Zeithaml (2004) point out that value equity affects a customer's (self-reported) switching propensity, a measure similar to loyalty intentions. Thus:

$\mathrm{H}_{1}$ : Perceived value equity has a positive impact on loyalty intentions.

Relationship equity. Relationship equity involves the elements that link a customer to a brand or a company (Rust, Lemon, and Zeithaml 2001). If perceived relationship equity is high, customers believe that they are well treated and handled with particular care. In addition, customers feel familiar with the brand, the store, or the employees of the store. They trust the quality of the products or the accurate delivery of the service. A positive experience with other customers is also indicative of relationship equity (Hennig-Thurau, Gwinner, and Gremler 2002). Relationship equity offers additional value for the customer. In line with the confirmation-disconfirmation paradigm, consumers who compare their expectations with their experiences and believe that they are treated better than others are likely to be satisfied with the offering, brand, or store and therefore will become more loyal. Studies by Gwinner, Gremler, and Bitner (1998), HennigThurau, Gwinner, and Gremler (2002), Patterson and Smith (2001), and Reynolds and Beatty (1999) have shown a strong relationship among the relationship construct, satisfaction, and loyalty. In line with Rust, Zeithaml, and Lemon (2000) and Rust, Lemon, and Zeithaml (2004), who show the influence of relationship equity on a customer's switching matrix, we assume that there is a positive impact on loyalty intentions. Thus:

$\mathrm{H}_{2}$ : Perceived relationship equity has a positive impact on loyalty intentions.

Brand equity. Brand equity is the subjective appraisal of a customer's brand choice. It is the value added to a product or service as a result of prior investments in the marketing mix (Keller 1993; Rust, Zeithaml, and Lemon 2000). If customers judge a particular brand as strong, unique, and desirable, they experience high brand equity (Verhoef, Langerak, and Donkers 2007). Because a brand attaches additional value to a product or service, it increases the value compared with a nonbranded product or service. If customers perceive a brand as having a favorable and strong image, it could positively influence their likelihood of choosing that particular brand rather than competing offerings. In a similar vein, Bolton, Lemon, and Verhoef (2002) suggest that a favorable perception of a brand could have an impact on affective commitment. Rust, Zeithaml, and Lemon (2000) state that brand equity is likely to influence a customer's willingness to stay, repurchase probability, and likelihood to recommend the brand. Thus:

\section{$\mathrm{H}_{3}$ : Perceived brand equity has a positive impact on loyalty intentions.}

\section{The Link Between Loyalty Intentions and Future Sales}

The theory of reasoned action (Fishbein and Ajzen 1975) states that loyalty intentions have an immediate influence on behavior. Loyalty intentions may result in a readiness to act (to buy). This readiness is accompanied by the consumer's willingness to search for a favorite offering, despite the considerable effort necessary to do so. Competitive offerings are not considered alternatives. However, action control studies imply that not all intentions are transformed into action (Kuhl and Beckmann 1985). Studies finding support for a positive link between intention and action are not without methodological biases. Most empirical studies consider the influence of loyalty intentions on self-reported behavior (e.g., Armstrong, Morwitz, and Kumar 2000; Evanschitzky and Wunderlich 2006; Harris and Goode 2004; LaBarbera and Mazursky 1983; Morwitz and Schmittlein 1992; Tobin 1959). A much stronger test of the intention-action link would be to relate loyalty intentions to actual purchases. To this end, Zeithaml (2000) notes that a more compelling relationship between customer purchase intentions and actual purchase behavior lacks confirmation. However, some studies that combine survey data with observed behavior have found a positive relationship. For 
example, Bolton, Kannan, and Bramlett (2000) show that repurchase probability rises by 1.67 times if intention increases by one point. Smith and Wright (2004) emphasize that an increase of one standard deviation in purchase intentions (from a rank of .5 to a rank of .8), meaning a corresponding increase of .36 standard deviations in sales, translates to a $\$ 500$ million increase in quarterly sales for a company. Studies by Nacif (2003) and Kamakura and colleagues (2002) confirm the positive influence of purchase intentions on actual customer retention. Therefore, a positive effect of loyalty intentions on future sales can be assumed. Thus:

$\mathrm{H}_{4}$ : Loyalty intentions have a positive impact on future sales.

\section{The Link Between Past Sales and Future Sales}

According to an expansion of the theory of reasoned action (Ajzen 2001; Bentler and Speckart 1979; Eagly and Chaiken 1993), a person's former behavior can explain his or her actual behavior. This means that consumers will prefer to buy at the same retailer they bought from on previous purchase occasions, even though they might perceive other retailers as providing the same benefits. Corstjens and Lal (2000) explain that this phenomenon is due to the psychological commitment to prior choices and customers' desire to minimize their cost of thinking. This so-called inertia effect is rational because it helps consumers achieve satisfactory outcomes by simplifying the decision-making process and saving the costs of making decisions. It takes place automatically and without conscious thought.

Many studies give empirical evidence for habitual behavior (e.g., Anderson and Srinivasan 2003; Beatty and Smith 1987; Gounaris and Stathakopoulos 2004; Huang and Yu 1999; Rust, Lemon, and Zeithaml 2004; see also the cited literature in Corstjens and Lal 2000). For example, Beatty and Smith (1987) demonstrate the strengths of the inertia effect by showing that $40 \%-60 \%$ of consumers buy at the same retailer because of habit. In summary, there is ample evidence to suggest that inertia plays a significant role in consumer choice. Thus:

$\mathrm{H}_{5}$ : Past sales have a positive impact on future sales.

Figure 1 provides the conceptual model of our study and summarizes the hypothesized links.

\section{Methodology}

\section{Data Collection Procedure and Sample}

We drew our sample from a European do-it-yourself retailer. The European retail market is highly competitive, and the retailer in our study is representative for this market in terms of size and success. ${ }^{1}$ The retailer has had a loyalty program in place for several years that tracks customers' purchase behavior. Customers who are members of the loyalty program were the participants of our study. We randomly selected 24,000 customers and sent questionnaires to them by mail in prepaid return envelopes along with a cover

${ }^{1}$ Because of guaranteed confidentiality, we are unable to provide further details about the retailer.
FIGURE 1

Conceptual Model and Hypotheses

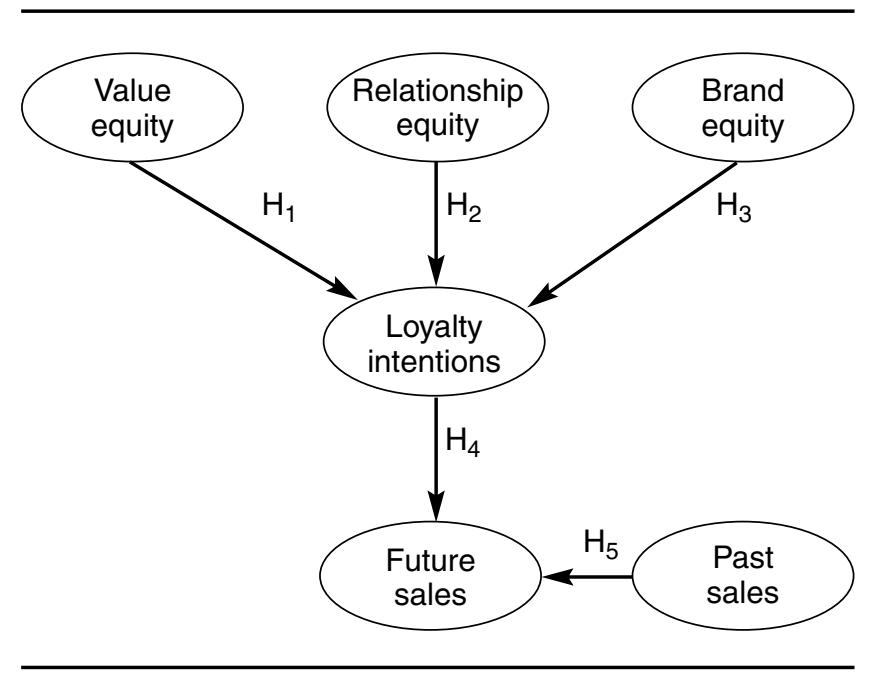

letter. The cover letter explained the purpose of the study, assured confidentiality of data, and thanked the participant. Furthermore, we used an incentive to increase the response rate: All participants were entered into a lottery to win cash prices between $€ 25$ and $€ 500$. To avoid any bias, the return envelopes were addressed to the researchers' university. A total of 5694 respondents returned usable questionnaires, for a response rate of $23.7 \%$. We then matched the transaction data to the survey data according to each customer's loyalty program identification number. We compared selected items from early and late respondents, following Armstrong and Overton's (1977) recommendations; these displayed no signs of nonresponse bias.

\section{Measures}

We developed the items for measuring the constructs of the study, drawing on prior research in the literature. We tested the initial item pool in qualitative interviews, focus-group discussions, and a pretest among 2400 customers of the same do-it-yourself retailer. This procedure led to the final survey instrument for the main study. We used multi-item seven-point Likert scales anchored by $1=$ "strongly agree" ("very satisfied," "best value") and $7=$ "strongly disagree" ("very unsatisfied," "poorest value").

We measured value equity with six items to understand the customers' evaluations of functional and cognitive value associated with the retail outlet. In accordance with the operationalizations of Baker and colleagues (2002), Rust, Zeithaml, and Lemon (2000), and Sirdeshmukh, Singh, and Sabol (2002), we asked the respondents to rate perceived value in general. Items that were part of the scale included price, product quality, service quality, convenience, and the tangible environment of the retailer.

We adapted the relationship equity measure from the relationship marketing research of De Wulf, OdekerkenSchröder, and Iacobucci (2001) and Hennig-Thurau, Gwinner, and Gremler (2002). This measure consists of five items that assess the preferred treatment customers receive when they are a member of a loyalty program. As a result 
of our pretest, we added one item for the relationship with the other customers because such relationships can also be considered a particularly relevant type of social benefit in a retail setting (Gwinner, Gremler, and Bitner 1998; Iacobucci and Hibbard 1999; Zeithaml and Bitner 1996).

We measured brand equity, which focuses on the overall perception of brand image, with four items, using the scale that Verhoef, Langerak, and Donkers (2004) introduced, with an additional item pertaining to the liking of the brand. We used "likable" because of its demonstrated importance in brand equity measures (Cox and Cox 1988; Darley and Smith 1993; Goodstein 1993; Keller 1991; Wansink and Ray 1992) and as a result of our qualitative studies conducted before this research.

We define loyalty intentions as customers' behavioral intentions to continue buying at a retail store in the future, accompanied by a deeply held commitment to that store. We adapted the scale from Zeithaml, Berry, and Parasuraman's (1996) behavioral intention battery and included two items.

We measured future sales using loyalty card data. In line with Baesens and colleagues (2002), Bolton, Kannan, and Bramlett (2000), Mittal and Kamakura (2001), Nacif (2003), and Seiders and colleagues (2005), we aggregated the sales over a particular period. In our case, we aggregated the sales from six months after completion of the questionnaire, in accordance with Nacif, whose study was also conducted in a retail context. Furthermore, planning periods of six months are common in retailing. Next, we discounted the sales to the date of the survey with an interest rate of 15\%, as Reinartz and Kumar (2003) suggest. We chose an annual interest rate of $15 \%$ because it was appropriate for marketing investments in the retailing industry in general and for that retailer in particular during the time of the survey. This is in line with the observation that the yearly discount rate appropriate for marketing investments varies from 12\% (Gupta, Lehmann, and Stuart 2004) to 20\% (Berger and Nasr 1998; Dwyer 1997).

We calculated past sales similarly to the measure of future sales. The only difference is that we considered the sales for the six months before the survey.

Following Gerbing and Anderson (1988), we conducted a confirmatory factor analysis to assess the reliability and validity of the multi-item scales. The coefficient alpha exceeded .7, the threshold typically proposed in the literature (Hair et al. 2006; Nunnally 1978). In addition, the composite reliabilities exceeded .6 for all constructs (Bagozzi and Yi 1988). The results appear in Table 1.

We assessed discriminant validity of the constructs using the criterion that Fornell and Larcker (1981) propose. As Table 2 shows, the criterion was met for all the constructs because the average variance extracted is larger than the squared correlation between any of the constructs. All the analyses suggest that the reliability and validity of the constructs in this study are acceptable. Following the procedure suggested by Hair and colleagues (2006) and Rust, Lemon, and Zeithaml (2004), we also administered the following tests to control for and assess the degree of multicollinearity: correlation between constructs, partial correlations, part correlations, principal components regression, and variance inflation factor. The results indicate that multicollinearity is not a severe issue in our data. Podsakoff and colleagues (2003) provide excellent guidelines for a potential statistical procedure to estimate and control for common method bias. In line with their reasoning, we analyzed our data (in particular, we performed a Harman's singlefactor test and ran competing confirmatory factor analysis models, as suggested by Podsakoff and colleagues [2003]) and ascertained that common method bias did not seem to be problematic in our study.

Following Anderson, Fornell, and Lehmann (1994), we used 3SLS regressions to estimate our model. Originally developed by Zellner and Theil (1962), 3SLS has many advantages: The main reason we chose 3SLS was to assess the monetary impact of a change in any of the equity drivers and loyalty intentions. When using 3SLS, we can specify that, all else being equal, a one-unit increase in loyalty intentions will result in an increase in future sales by $€ X$. If we had used structural equations modeling, we could have argued only about the relative strength of the links and would not have been able to draw any conclusion about the monetary value of an increase in one of the drivers. Furthermore, 3SLS, which adds a correction for heteroskedasticity, is a full information method because all the parameters of the model are estimated jointly (Berndt et al. 1974). Therefore, it is efficient (Basman 1957) and, according to Greene (2007), robust to nonnormality.

We used factor scores of the constructs as independent variables in our regression analysis. This standardized the indicators so that we could use them in regression analysis.

\section{Results}

\section{Model Results}

To test our hypotheses, we estimate the following regression equations:

$$
\mathrm{LI}_{\mathrm{it}}=\alpha_{0}+\alpha_{1} \times \mathrm{VE}_{\mathrm{it}}+\alpha_{2} \times \mathrm{RE}_{\mathrm{it}}+\alpha_{3} \times \mathrm{BE}_{\mathrm{it}}+\varepsilon_{\mathrm{i}},
$$

and

$$
\mathrm{S}_{\mathrm{it}}=\beta_{\mathrm{o}}+\beta_{1} \times \mathrm{LI}_{\mathrm{it}}+\beta_{2} \times \mathrm{S}_{\mathrm{it}-1}+\varepsilon_{\mathrm{i}}
$$

where

$$
\begin{aligned}
\mathrm{LI} & =\text { loyalty intentions, } \\
\mathrm{VE} & =\text { value equity } \\
\mathrm{RE} & =\text { relationship equity, and } \\
\mathrm{BE} & =\text { brand equity. }
\end{aligned}
$$

Overall, we found strong support for our model. The three drivers of loyalty intentions — value equity, brand equity, and relationship equity-explained $44.69 \%$ of the variation in loyalty intention ratings. Value equity by itself would explain $36.85 \%$, brand equity would explain $36.91 \%$, and relationship equity would explain $20.40 \%$ of variation in loyalty intentions. However, note that these percentages cannot be added up, because the equity drivers are not mutually exclusive.

Brand equity has a strong impact on loyalty intentions $(\gamma=.32 ; \mathrm{t}=21.73, p<.01)$, closely followed by value equity with an almost identical coefficient $(\gamma=.32 ; \mathrm{t}=$ 
TABLE 1

Description of Items Used to Measure the Constructs

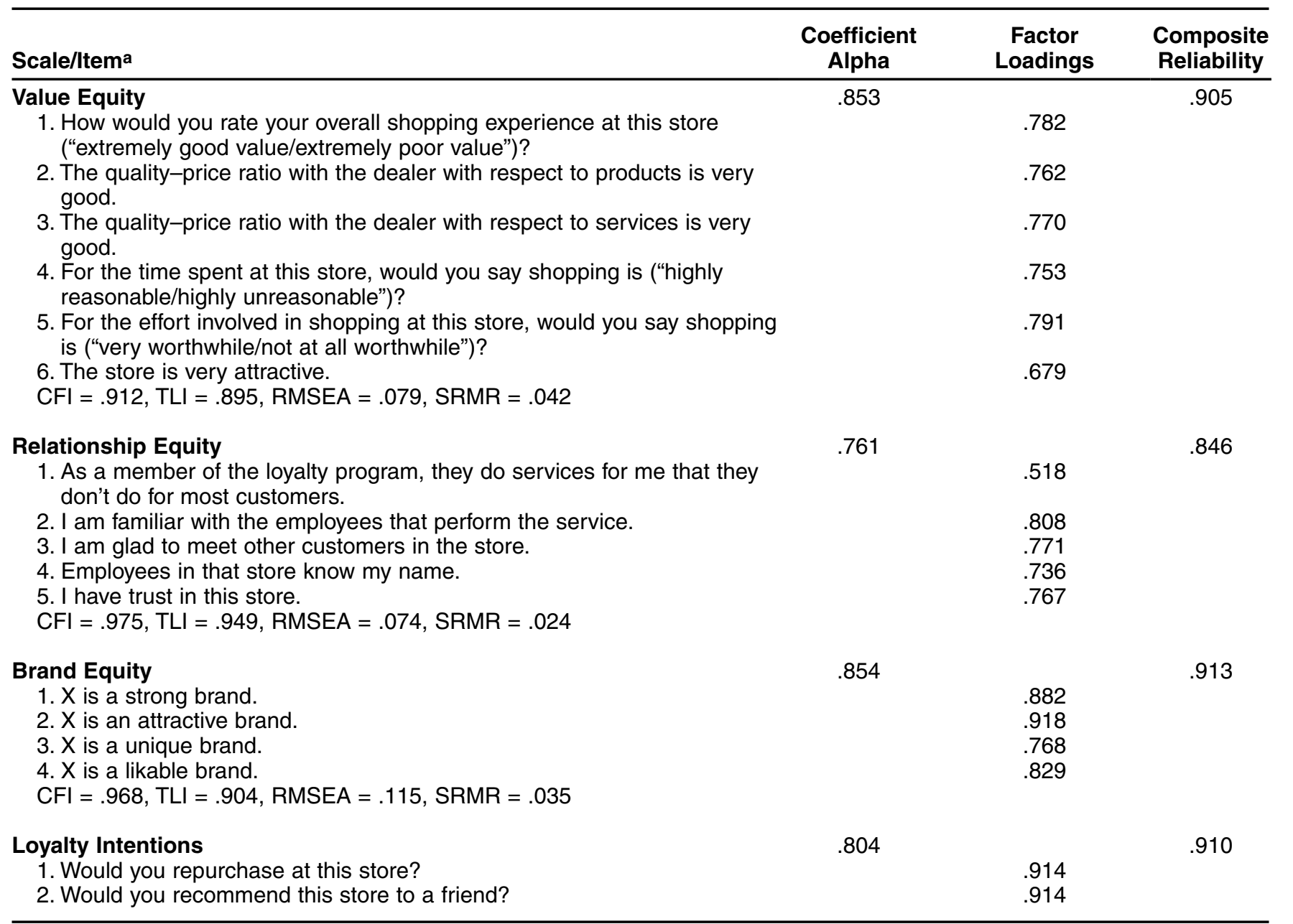

aWe measured the items using seven-point Likert scales anchored by "strongly agree" (1) and "strongly disagree" (7) and "very satisfied" (1) and "very unsatisfied" (7), unless otherwise noted.

Notes: $\mathrm{CFI}=$ comparative fit index, TLI = Tucker-Lewis index, RMSEA = root mean square error of approximation, and SRMR $=$ standardized root mean square residual.

TABLE 2

Correlation Matrix

\begin{tabular}{lcccc}
\hline & $\begin{array}{c}\text { Value } \\
\text { Equity }\end{array}$ & $\begin{array}{c}\text { Relation- } \\
\text { ship } \\
\text { Equity }\end{array}$ & $\begin{array}{c}\text { Brand } \\
\text { Equity }\end{array}$ & $\begin{array}{c}\text { Loyalty } \\
\text { Intentions }\end{array}$ \\
\hline $\begin{array}{l}\text { Value equity } \\
\begin{array}{l}\text { Relationship } \\
\text { equity }\end{array}\end{array}$ & 1 & & & \\
$\begin{array}{l}\text { Brand equity } \\
\text { Loyalty }\end{array}$ & .509 & 1 & & \\
$\quad$ intentions & .693 & .506 & 1 & \\
AVE & .608 & .453 & .610 & 1 \\
\hline
\end{tabular}

Notes: AVE = average variance extracted.

$21.68, p<.01)$ and relationship equity $(\gamma=.13 ; \mathrm{t}=10.30$, $p<.01$ ). Therefore, the data support $\mathrm{H}_{1}, \mathrm{H}_{2}$, and $\mathrm{H}_{3}$. With regard to the drivers of future sales, the results indicate that loyalty intentions have a direct and positive impact on future sales $(\gamma=20.88 ; \mathrm{t}=2.38, p<.01)$, in support of $\mathrm{H}_{4}$.
We also controlled for sales made to each customer for the six-month period before this survey. The results support an inertia effect, with a coefficient of $\gamma=.63(\mathrm{t}=52.22, p<$ .01 ), indicating that past sales are good predictors of future sales. Therefore, $\mathrm{H}_{5}$ is supported as well. Overall, our model explained $34.71 \%$ of the variance of future sales. The results are summarized as follows:

$$
\begin{aligned}
\mathrm{LI}=-.017 \text { n.s. } & +.32^{* *} \times \mathrm{VE}+.13^{* *} \times \mathrm{RE}+.32^{* *} \\
& \times \mathrm{BE}+\varepsilon, \text { adjusted } \mathrm{R}^{2}=.4469,
\end{aligned}
$$

and

$$
\begin{gathered}
\mathrm{S}_{\mathrm{t}}=156.45^{* *}+20.88^{*} \times \mathrm{LI}+.63^{* *} \times \mathrm{S}_{\mathrm{t}-1}+\varepsilon, \\
\text { adjusted } \mathrm{R}^{2}=.3471
\end{gathered}
$$

where

$$
\begin{aligned}
\mathrm{S}_{\mathrm{t}} & =\text { future sales; } \\
\mathrm{S}_{\mathrm{t}-1} & =\text { past sales; } \\
\varepsilon & =\text { error term (normally distributed); and } \\
\text { n.s. } & =\text { nonsignificant, }{ }^{*} p<.05, \text { and } * * p<.01 .
\end{aligned}
$$


Next, we compare the original model with one that includes direct links from the three equity drivers to future sales. To assess the difference in fit between the two models, we performed a likelihood ratio test. This new model would have three degrees of freedom less. The results show a significant improvement in the fit (likelihood ratio $=$ 17.22, $\Delta$ d.f. $=3, p<.01)$ between the original model and the new model, which includes three direct links between the equity drivers and future sales. In assessing total Rsquare of the new model, we find a total variance explained of $34.85 \%$, compared with $34.71 \%$ in the original model. It seems that the positive impact of the three equity drivers is largely mediated by loyalty intentions. ${ }^{2}$

We also assess the monetary impact of a change in loyalty intentions. All else being equal, an increase of loyalty intentions by one point would result in an increase of future sales by $€ 20.88$. If we take all 1.5 million customers of the retailer into account, this would mean an increase of future sales of $€ 31.32$ million.

\section{Test of Model Stability}

We also ran several alternative models-for example, twopart equity frameworks considering only value equity and relationship equity, relationship equity and brand equity, and value equity and brand equity; one-part equity frameworks considering only value equity, relationship equity, and brand equity; and a simple regression model with all equities, loyalty intentions, and past sales directly influencing future sales. Because none of these models show better fit indexes, our previously mentioned model seems to be a good representation of the data. ${ }^{3}$

The model we propose uses 3SLS estimation. This technique applies linear regressions to estimate coefficients. However, there might be nonlinear effects between the constructs. To address this issue, we ran different nonlinear regressions between the three equity drivers and loyalty intentions and between loyalty intentions and future sales. We conducted these analyses in an exploratory way because we had no a priori hypothesis about the type of nonlinearity. The results show that using nonlinear regressions does not significantly improve model fit or the explanatory power of the model. This gives us faith in the stability of our conceptual linear model. ${ }^{4}$

\section{Discussion}

Customer centrism is essential for a firm to flourish. Customer equity models offer a theoretical framework for making the firm customer centered. Our study was a result of opportunities provided by the existing literature in the performance outcomes of the three customer equity driversvalue equity, brand equity, and relationship equity. We used both survey data and real purchase data to examine the

${ }^{2}$ For brand equity, there is full mediation because the direct link is not significant; the remaining two links are significant, so we have a partial mediation.

${ }^{3}$ Additional information about the competing models is available on request.

${ }^{4}$ Additional information about the nonlinear models is available on request. effects of the three equity drivers on consumers' loyalty intentions and their future purchase behavior, while controlling for past purchase behavior.

Our study shows that all three customer equity drivers positively influence customers' loyalty intentions toward a firm and that customers' loyalty intentions have a positive effect on the firm's future sales. Among the three drivers, brand equity and value equity are of primary importance in establishing future sales. This finding is in agreement with Lemon, Rust, and Zeithaml (2001), who note that value is the keystone of the relationship of a customer with a firm. If the product or service offered by the firm does not meet customer expectations, there is no need to establish brand equity and relationship equity. Our study also finds relationship equity to be a significant driver of loyalty intentions.

The study also shows that future sales are directly influenced by loyalty intentions and past sales. Furthermore, they are indirectly influenced by value equity, brand equity, and relationship equity. Considering the equity drivers in particular, it is critical to understand that future sales could be influenced by marketing activities targeted toward increasing the perceived equity of the three strategic fields of investment: value, brand, and relationship.

By providing the statistical and implementation details necessary to implement the customer equity framework in practice, our study demonstrates that the customer equity drivers identified by Rust, Zeithaml, and Lemon (2000) can significantly predict future sales, even after we control for the current sales level. This means that apart from the wellknown inertia effect, we identify drivers of future sales.

\section{Managerial Implications}

This study offers some helpful implications for managers. Our finding that value equity is of primary importance in establishing future sales suggests that a firm must meet customers' expectations, which can be considered an objective assessment of the utility of the firm's products and services. Value equity represents a customer's balancing of what is given up (price) and what is received in return (value). A firm could consider delivering to the customer different aspects of value, including quality service, quality product, price, convenience, and an engaging shopping environment. However, in doing so, managers must be cautious because treating all customers as homogeneous could misrepresent the value equity $\rightarrow$ loyalty intentions $\rightarrow$ future sales relationship since the importance of value equity depends on the industry, the maturity of the firm, and the customer decision-making process (Lemon, Rust, and Zeithaml 2001). Therefore, it is important that managers uncover the level of influence of various aspects of value on future sales for different customer segments in their business so that resources can be appropriately allocated, thus maximizing value equity. For example, in retailing, value could vary by type of shopper-those who seek low prices, those who are willing to pay higher prices for superior service or convenience, and those who buy at certain prestigious stores for status by paying very high prices. Thus, the store manager must choose from several possibilities to strengthen the value perception in the customer's mind, such as offering 
low prices, improving the quality of assortment, enhancing store ambience, and training employees to provide better customer service.

Our finding that brand equity is of equal importance to value equity in predicting loyalty intentions and, ultimately, in establishing future sales is noteworthy. When a brand is perceived as attractive and unique, customers are less likely to switch. Thus, managers must focus on establishing and sustaining brand equity to influence loyalty directly. In establishing brand equity, managers must focus on building brand awareness, improving brand image, and ensuring the consistency of delivery of a brand's promise at a level that surpasses the customer's expectations. Understanding the changing consumer environment and constantly upgrading the brand to ensure that the brand maintains its level of relevance to an ever-demanding consumer will help managers sustain brand equity. Managers must avoid the common practice of employing price promotions and unwise brand extensions with the aim to achieve short-term financial results. These could cause irreversible deterioration of the value of the brand. In the retail industry, with its many competing suppliers, branding is especially important to influence customer perceptions positively and drive store choice and loyalty (Ailawadi and Keller 2004; Peterson and Balasubramanian 2002; Woodside and Walser 2006). Grewal, Levy, and Lehmann (2004) note that the rise of the retailer as a brand is one of the most important trends in retailing. Retailer brands, such as Wal-Mart, H\&M, IKEA, and Tesco, demonstrate their success by their unique, strong, and distinct brand image. These brands have gone beyond their advertising propositions through their product offering, the in-store events, and the visual excitement in each store.

Furthermore, our study reveals that relationship equity is a significant driver of future sales. This suggests that firms must increase relationship equity by establishing and maintaining sound relationships with customers that will help cement customers to the firm. To achieve this, firms must consider setting up initiatives, such as community activities and loyalty programs, that provide "aspirational value" and establishing learning relationships with customers (Lemon, Rust, and Zeithaml 2001). Barnes (2001, title page) notes that "it's all about how you make them feel." For example, a retailer could motivate customers to build a community that rests on a structured set of relationships among "fans" of a brand (Algesheimer, Dholakia, and Herrmann 2005; Muniz and O'Guinn 2001). The retailer could benefit from including characteristics of a community in the loyalty program. Rosenbaum, Ostrom, and Kuntze (2005) indicate that members of loyalty programs who are engaged in the brand's community are more loyal than members of programs who are not offered this relationship benefit. By amplifying the nonfinancial benefits provided to the members of the loyalty program, the retailer could become more trustworthy (Winer 2001) while also creating switching barriers. In addition, establishing different "clubs" within the loyalty program could be beneficial. For example, following the approach of Tesco, which offers different kinds of club memberships (e.g., baby and toddler club, food club, wine club, healthy-living club), members could be approached according to their needs, which may lead them to be emotionally bound to the retailer. Another way to achieve better relationship equity would be to improve the social value that comes with the relationship with the retailer. In a retail setting, as in our study, employees play a pivotal role. It is necessary to have the same qualified and committed service personnel for a long time, so that customers can find "their" service employee (HarrisonWalker and Coppett 2003). Babakus, Beinstock, and Scotter (2004), Rucci, Kirn, and Quinn (1998), Stock (2005), and Weitz and Bradford (1999) suggest that employing highly skilled and motivated service personnel is one of the success factors in retailing.

Finally, a challenge for managers who want to improve their marketing accountability is related to the lack of scientific approaches that link marketing actions with customer spending actions. Our study meets this challenge and informs managers how the proposed model could be applied to companies in understanding the drivers that are most important for influencing the buying behavior of their customers. This study also helps make the actions of managers accountable with respect to their ultimate impact on customers. These actions are critical in the retail industry, in which firms spend a considerable percentage of their revenues on marketing. The results of our study suggest that the limited marketing budget should be spent first on actions and programs to increase or maintain brand and value equity, followed by spending to enhance relationship equity. However, these results may apply only to the particular retail setting of our study: do-it-yourself retailing. Nevertheless, and in line with findings from related empirical studies (e.g., Rust, Lemon, and Zeithaml 2004; Rust, Zeithaml, and Lemon 2000), we would expect the three equity drivers to significantly predict loyalty intentions and future sales in different retail settings as well; only the relative importance might differ.

\section{Limitations and Further Research}

The substantive findings of our study must be viewed in the light of their limitations. First, our study analyzed a particular retailer from one industry. Therefore, caution must be exercised in generalizing our findings to other retail organizations/industries. For an industry in which product quality differs largely among providers, value equity might be a source of sustainable competitive advantage, whereas in industries or retail settings in which involvement is low, establishing brand communities might not be a good investment. Second, we analyzed data from customers who are current members of the loyalty program of this particular retailer. Thus, we could not draw any conclusions for potential customers and related acquisition strategies. A good acquisition strategy might indeed be to build a strong brand. Third, we used questionnaire data from one point in time only. By doing so, we assumed that there was no time lag between a customer's perception of the three equity drivers and the consequences, such as loyalty intentions. By establishing more measurement points over time, stronger inferences could be made about the constructs and their causal sequence (Bolton 1998). In addition, examining the impact of a change in some marketing activity on related customer 
perceptions and outcome variables would be a promising area for further research.

It would also be fruitful to discuss the complex concept of loyalty intentions in more detail (for an overview, see Malle, Moses, and Baldwin 2001). The model should be reconciled with psychological approaches to the study of explanation, including causal judgment theory, the intentional approach, the communicative approach, and/or the folk-theoretical approach.
Finally, it might be useful to examine the extent to which the three types of equity drivers have different effects on specific aspects of purchase behaviors. For example, relationship equity may have stronger effects on the number of purchases per month, whereas brand and value equity may have an impact on the number of items purchased per visit. Further research in this area would deepen the understanding of the impact of equity drivers on loyalty intentions and more specific customer purchase behavior.

\section{REFERENCES}

Adams, J. Stacy (1965), "Inequity in Social Exchange," in Advances in Experimental Social Psychology, Vol. 2, Leonard Berkowitz, ed. New York: Academic Press, 267-99.

- Ailawadi, Kusum L. and Kevin L. Keller (2004), "Understanding Retail Branding: Conceptual Insights and Research Priorities," Journal of Retailing, 80 (4), 331-42.

-Ajzen, Icek (2001), "Nature and Operation of Attitudes," Annual Review of Psychology, 52 (1), 27-58.

-Algesheimer, René, Utpal M. Dholakia, and Andreas Herrmann (2005), "The Social Influence of Brand Community: Evidence from European Car Clubs," Journal of Marketing, 69 (July), 19-34.

-Anderson, Eugene W., Claes Fornell, and Donald R. Lehmann (1994), "Customer Satisfaction, Market Share, and Profitability: Findings from Sweden," Journal of Marketing, 58 (July), 53-66.

-Anderson, Rolph E. and Srini S. Srinivasan (2003), "ESatisfaction and E-Loyalty: A Contingency Framework," Psychology \& Marketing, 20 (2), 123-38.

Armstrong, J. Scott and John U. Farley (1969), "A Note on the Use of Markov Chains in Forecasting Store Choice," Management Science, 16 (4), B281-85.

- Vicki G. Morwitz, and V. Kumar (2000), "Sales Forecasts for Existing Consumer Products and Services: Do Purchase Intentions Contribute to Accuracy?" International Journal of Forecasting, 16 (3), 383-97.

- _ and Terry S. Overton (1977), "Estimating Nonresponse Bias in Mail Surveys," Journal of Marketing Research, 14 (August), 396-402.

- Babakus, Emin, Carol C. Beinstock, and James R. Van Scotter (2004), "Linking Perceived Quality and Customer Satisfaction to Store Traffic and Revenue Growth," Decision Sciences, 35 (4), 713-37.

Baesens, Bart, Stijn Viaene, Dirk Van den Poel, Jan Vanthienen, and Guido Dedene (2002), "Bayesian Neural Network Learning for Repeat Purchase Modeling in Direct Marketing," European Journal of Operational Research, 138 (1), 191-211.

-Bagozzi, Richard P. and Youjae Yi (1988), "On the Evaluation of Structural Equation Models," Journal of the Academy of Marketing Science, 16 (1), 74-94.

- Baker, Julie, A. Parasuraman, Dhruv Grewal, and Glenn B. Voss (2002), "The Influence of Multiple Store Environment Cues on Perceived Merchandise Value and Patronage Intentions," Journal of Marketing, 66 (April), 120-41.

Barnes, James G. (2001), Secrets of Customer Relationship Management: It's All About How You Make Them Feel. New York: McGraw-Hill.

-Basman, Robert L. (1957), "A Generalized Classical Method of Linear Estimation of Coefficients in a Structural Equation," Econometrica, 25 (1), 77-83.

Beatty, Sharon E. and Scott M. Smith (1987), "External Search Effort: An Investigation Across Several Product Categories," Journal of Consumer Research, 14 (1), 83-95.
Bentler, Peter M. and George Speckart (1979), "Models of Attitude-Behavior Relations," Psychological Review, 86 (5), 452-64.

-Berger, Paul D. and Nada I. Nasr (1998), "Customer Lifetime Value: Marketing Models and Applications," Journal of Interactive Marketing, 12 (1), 17-30.

Berndt, Ernst K., Bronwyn H. Hall, Robert E. Hall, and Jerry A. Hausman (1974), "Estimation and Inference in Nonlinear Structural Models," Annals of Economic and Social Measurement, 3-4, 653-65.

Blattberg, Robert C. and John Deighton (1996), "Manage Marketing by the Customer Equity Test," Harvard Business Review, 74 (4), 136-44.

Bolton, Ruth N. (1998), "A Dynamic Model of the Duration of the Customer's Relationship with a Continuous Service Provider: The Role of Satisfaction," Marketing Science, 17 (1), 45-65.

- P.K. Kannan, and Matthew D. Bramlett (2000), "Implications of Loyalty Program Membership and Service Experiences for Customer Retention and Value," Journal of the Academy of Marketing Science, 28 (1), 95-108.

- Katherine N. Lemon, and Peter C. Verhoef (2004), "The Theoretical Underpinnings of Customer Asset Management: A Framework and Propositions for Future Research," Journal of the Academy of Marketing Science, 32 (3), 271-92.

- Bronnenberg, Bart J. and Luc Wathieu (1996), "Asymmetric Promotion Effects and Brand Positioning," Marketing Science, 15 (4), 379-94.

Corstjens, Marcel and Rajiv Lal (2000), "Building Store Loyalty Through Store Brands," Journal of Marketing Research, 37 (August), 281-91.

Cox, Dena S. and Anthony D. Cox (1988), "What Does Familiarity Breed? Complexity as a Moderator of Repetition Effects in Advertisement Evaluation," Journal of Consumer Research, 15 (1), 111-16.

Darley, William K. and Robert E. Smith (1993), "Advertising Claim Objectivity: Antecedents and Effects," Journal of Marketing, 57 (October), 100-113.

De Wulf, Kristof, Gaby Odekerken-Schröder, and Dawn Iacobucci (2001), "Investments in Consumer Relationships: A CrossCountry and Cross-Industry Exploration," Journal of Marketing, 65 (October), 33-50.

-Dick, Alan S. and Kunal Basu (1994), "Customer Loyalty: Toward an Integrated Conceptual Framework," Journal of the Academy of Marketing Science, 22 (2), 99-113.

Dwyer, F. Robert (1997), "Customer Lifetime Valuation to Support Marketing Decision Making," Journal of Direct Marketing, 11 (4), 6-13.

Eagly, Alice H. and Shelly Chaiken (1993), The Psychology of Attitudes. Fort Worth, TX: Harcourt Brace.

-Ehrenberg, Andrew S.C. (1965), "An Appraisal of Markov BrandSwitching Models," Journal of Marketing Research, 2 (November), 347-62. 
DEvanschitzky, Heiner and Maren Wunderlich (2006), "An Examination of Moderator Effects in the Four-Stage Loyalty Model," Journal of Service Research, 8 (4), 330-45.

Fishbein, M. and I. Ajzen (1975), Belief, Attitude, Intention and Behavior: An Introduction to Theory and Research. Reading, MA: Addison-Wesley.

Fornell, Claes and David F. Larcker (1981), "Evaluating Structural Equation Models with Unobservable Variables and Measurement Error," Journal of Marketing Research, 18 (February), 39-50.

Gerbing, David W. and James C. Anderson (1988), "An Updated Paradigm for Scale Development Incorporating Unidimensionality and Its Assessments," Journal of Marketing Research, 25 (May), 186-92.

Goodstein, Ronald C. (1993), "Category-Based Applications and Extensions in Advertising: Motivating More Extensive Ad Processing," Journal of Consumer Research, 20 (1), 87-99.

- Gounaris, Spiros and Viasis Stathakopoulos (2004), "Antecedents and Consequences of Brand Loyalty: An Empirical Study," Journal of Brand Management, 11 (4), 283-306.

Greene, William. H. (2007), Econometric Analysis, 6th ed. Upper Saddle River, NJ: Prentice Hall.

-Grewal, Druv, Michael Levy, and Donald R. Lehmann (2004), "Retail Branding and Customer Loyalty: An Overview," Journal of Retailing, 80 (4), 249-52.

- Gupta, Sunil, Donald R. Lehmann, and Jennifer A. Stuart (2004), "Valuing Customers," Journal of Marketing Research, 41 (February), 7-18.

Gwinner, Kevin P., Dwayne D. Gremler, and Mary J. Bitner (1998), "Relational Benefits in Services Industries: The Customer's Perspective," Journal of the Academy of Marketing Science, 26 (2), 101-114.

Hair, Joseph F., Jr., Bill Black, Barry J. Babin, Rolph E. Anderson, and Ronald L. Tatham (2006), Multivariate Data Analysis, 6th ed. Upper Saddle River, NJ: Prentice Hall.

-Harris, Lloyd C. and Mark M.H. Goode (2004), "The Four Levels of Loyalty and the Pivotal Role of Trust: A Study of Online Service Dynamics," Journal of Retailing, 80 (2), 139-58.

-Harrison-Walker, L. Jean and John I. Coppett (2003), "Building Bridges: The Company-Customer Relationship," Journal of Business-to-Business Marketing, 10 (4), 49-72.

-Hennig-Thurau, Thorsten, Kevin P. Gwinner, and Dwayne D. Gremler (2002), "Understanding Relationship Marketing Outcomes: An Integration of Relational Benefits and Relationship Quality," Journal of Service Research, 4 (3), 230-47.

Homans, George C. (1961), Social Behavior: Its Elementary Forms. New York: Harcourt Brace.

-Huang, Ming-Hui and Shihti Yu (1999), "Are Consumers Inherently or Situationally Brand Loyal? A Set Intercorrelation Account for Conscious Brand Loyalty and Nonconscious Inertia," Psychology \& Marketing, 16 (6), 523-44.

- Iacobucci, Dawn and Jonathan D. Hibbard (1999), "Towards an Encompassing Theory of Business Marketing Relationships (BMRS) and Interpersonal Commercial Relationships (ICRS): An Empirical Generalization," Journal of Interactive Marketing, 13 (3), 13-33.

-Johnson, Michael D., Andreas Herrmann, and Frank Huber (2006), "The Evolution of Loyalty Intentions," Journal of Marketing, 70 (April), 122-32.

-Kamakura, Wagner A., Vikas Mittal, Fernando de Rosa, and José Afonso Mazzon (2002), "Assessing the Service-Profit Chain," Marketing Science, 21 (3), 294-317.

-Keiningham, Timothy L., Tiffany Perkins-Munn, and Heather Evans (2003), "The Impact of Customer Satisfaction on Shareof-Wallet in a Business-to-Business Environment," Journal of Service Research, 6 (1), 37-50.

-Keller, Kevin L. (1991), "Cue Compatibility and Framing in Advertising," Journal of Marketing Research, 28 (February), $42-57$.
(1993), "Conceptualizing, Measuring, and Managing Customer-Based Brand Equity," Journal of Marketing, 57 (January), 1-22.

Kuhl, Julius and Jurgen Beckmann (1985), Action Control: From Cognition to Behavior. Heidelberg: Springer.

-Kumar, V., Katherine N. Lemon, and A. Parasuraman (2006), "Managing Customers for Value: An Overview and Research Agenda," Journal of Service Research, 9 (2), 87-94.

LaBarbera, Priscilla A. and David Mazursky (1983), "A Longitudinal Assessment of Consumer Satisfaction/Dissatisfaction: The Dynamic Aspect of the Cognitive Process," Journal of Marketing Research, 20 (November), 393-404.

-Lam, Shun Y., Venkatesh Shankar, M. Krishna Erramilli, and Bvsan Murthy (2004), "Customer Value, Satisfaction, Loyalty, and Switching Costs: An Illustration from a Business-toBusiness Service Context," Journal of the Academy of Marketing Science, 32 (3), 293-311.

Lemon, Katherine N., Roland T. Rust, and Valarie A. Zeithaml (2001), "What Drives Customer Equity?" Marketing Management, 10 (1), 20-25.

Malle, Bertram F., Louis J. Moses, and Dare A. Baldwin (2001), "Introduction: The Significance of Intentionality," in Intentions and Intentionality: Foundations of Social Cognition, Bertram F. Malle, Louis J. Moses, and Dare A. Baldwin, eds. Cambridge, MA: The MIT Press/Bradford Books, 1-26.

Mittal, Vikas and Wagner A. Kamakura (2001), "Satisfaction, Repurchase Intent, and Repurchase Behavior: Investigating the Moderating Effect of Customer Characteristics," Journal of Marketing Research, 38 (February), 131-42.

-Morwitz, Vicki G. and David Schmittlein (1992), "Using Segmentation to Improve Sales Forecasts Based on Purchase Intent: Which 'Intenders' Actually Buy?" Journal of Marketing Research, 29 (November), 391-405.

-Muniz, Albert M., Jr., and Thomas C. O'Guinn (2001), "Brand Community," Journal of Consumer Research, 27 (4), 412-32.

Nacif, Roberta C. (2003), Online Customer Loyalty: Forecasting the Repatronage Behavior of Online Retail Customers. Wiesbaden, Germany: Gabler.

Nunnally, Jum C. (1978), Psychometric Theory, 2d ed. New York: McGraw-Hill.

- (1997), Satisfaction: A Behavioral Perspective on the Consumer. Boston: McGraw-Hill.

Oliver, Richard L. (1997), Satisfaction: A Behavioral Perspective on the Consumer. Boston: McGraw-Hill.

- _ and Wayne S. DeSarbo (1988), "Response Determinants in Satisfaction Judgments," Journal of Consumer Research, 14 (4), 495-507.

-Patterson, Paul G. and Tasman Smith (2001), "Relationship Benefits in Service Industries: A Replication in a Southeast Asian Context," Journal of Services Marketing, 15 (6-7), 425-43.

-Peterson, Robert A. and Sridhar Balasubramanian (2002), "Retailing in the 21st Century: Reflections and Prologue to Research," Journal of Retailing, 78 (1), 9-16.

Podsakoff, Philip M., Scott B. MacKenzie, Jeong-Yeon Lee, and Nathan P. Podsakoff (2003), "Common Method Biases in Behavioral Research: A Critical Review of the Literature and Recommended Remedies," Journal of Applied Psychology, 88 (5), 879-903.

Reinartz, Werner J. and V. Kumar (2000), "On the Profitability of Long-Life Customers in a Noncontractual Setting: An Empirical Investigation and Implications for Marketing," Journal of Marketing, 64 (October), 17-35.

- and (2003), "The Impact of Customer Relationship Characteristics on Profitable Lifetime Duration," Journal of Marketing, 67 (January), 77-99.

-Reynolds, Kristy E. and Sharon E. Beatty (1999), "Customer Benefits and Company Consequences of CustomerSalesperson Relationships in Retailing," Journal of Retailing, 75 (1), 11-32. 
Rosenbaum, Mark S., Amy L. Ostrom, and Ronald Kuntze (2005), "Loyalty Programs and a Sense of Community," Journal of Services Marketing, 19 (4), 222-33.

Rucci, Anthony J., Steven P. Kirn, and Richard T. Quinn (1998), "The Employee-Customer-Profit Chain at Sears," Harvard Business Review, 76 (1), 82-97.

Rust, Roland T., Katherine N. Lemon, and Valarie A. Zeithaml (2001), "Where Should the Next Marketing Dollar Go?" Marketing Management, 10 (3), 25-28.

$\longrightarrow$ —_ _ _ a _ a _ (2004), "Return on Marketing: Using Customer Equity to Focus Marketing Strategy," Journal of Marketing, 68 (January), 109-127.

- Valarie A. Zeithaml, and Katherine N. Lemon (2000), Driving Customer Equity: How Customer Lifetime Value Is Reshaping Corporate Strategy. New York: The Free Press.

-Seiders, Kathleen, Glenn B. Voss, Dhruv Grewal, and Andrea L. Godfrey (2005), "Do Satisfied Customers Buy More? Examining Moderating Influences in a Retailing Context," Journal of Marketing, 69 (October), 26-43.

-Silvestro, Rhian and Stuart Cross (2000), "Applying the Service Profit Chain in a Retail Environment: Challenging the 'Satisfaction Mirror,"' International Journal of Service Industry Management, 11 (3), 244-68.

-Sirdeshmukh, Deepak, Jagdip Singh, and Barry Sabol (2002), "Consumer Trust, Value, and Loyalty in Relational Exchanges," Journal of Marketing, 66 (January), 15-37.

-Smith, Rodney E. and William F. Wright (2004), "Determinants of Customer Loyalty and Financial Performance," Journal of Management Accounting Research, 16 (1), 183-205.

-Stahl, Heinz K., Kurt Matzler, and Hans H. Hinterhuber (2003), "Linking Customer Lifetime Value with Shareholder Value," Industrial Marketing Management, 32 (4), 267-79.

-Stock, Ruth M. (2005), "Can Customer Satisfaction Decrease Price Sensitivity in Business-to-Business Markets?" Journal of Business-to-Business Marketing, 12 (3), 59-87.

Taylor, Steven A., Gary L. Hunter, and Timothy A. Longfellow (2006), "Testing an Expanded Attitude Model of Goal-Directed Behavior in a Loyalty Context," Journal of Consumer Satisfaction, Dissatisfaction and Complaining Behavior, 19, 18-39.

- Tobin, James (1959), "On the Predictive Value of Consumer Intentions and Attitudes," Review of Economics and Statistics, 41 (1), 1-11.

-Verhoef, Peter C. (2003), "Understanding the Effect of Customer Relationship Management Efforts on Customer Retention and Customer Share Development," Journal of Marketing, 67 (October), 30-45.
Fred Langerak, and Bas Donkers (2004), "Understanding Brand and Dealer Retention in the New Car Market: The Moderating Role of Brand Type," Research Paper No. ERS-2004084-MKT, Erasmus Research Institute of Management, RSM Erasmus University.

$\longrightarrow$ Dealer Retention in the New Car Market: The Moderating Role of Brand Tier," Journal of Retailing, 83 (1), 97-113.

-Villanueva, Julian and Dominique M. Hanssens (2007), "Customer Equity: Measurement, Management and Research Opportunities," Foundations and Trends in Marketing, 1 (1), $1-95$.

Walster, Elaine, G. William Walster, and Ellen Berscheid (1978), Equity: Theory and Research. Boston: Allyn \& Bacon.

Wansink, Brian and Michael L. Ray (1992), "Estimating an Advertisement's Impact on One's Consumption of a Brand," Journal of Advertising Research, 32 (3), 9-16.

-Weitz, Barton A. and Kevin D. Bradford (1999), "Personal Selling and Sales Management: A Relationship Marketing Perspective," Journal of the Academy of Marketing Science, 27 (2), 241-54.

Winer, Russell S. (2001), "A Framework for Customer Relationship Management," California Management Review, 43 (4), 89-105.

-Woodside, Arch G. and Martin G. Walser (2006), "Building Strong Brands in Retailing," Journal of Business Research, 60 (1), $1-10$.

- Yang, Zhilin and Robin T. Peterson (2004), "Customer Perceived Value, Satisfaction, and Loyalty: The Role of Switching Costs," Psychology \& Marketing, 21 (10), 799-822.

Zeithaml, Valarie A. (2000), "Service Quality, Profitability and the Economic Worth of Customers: What We Know and What We Need to Learn," Journal of the Academy of Marketing Science, 28 (1), 67-85.

—_ Leonard L. Berry, and A. Parasuraman (1996), "The Behavioral Consequences of Service Quality," Journal of Marketing, 60 (April), 31-46.

and Mary J. Bitner (1996), Services Marketing. New York: McGraw-Hill.

Zellner, Arnold and Henri Theil (1962), "Three-Stage Least Squares: Simultaneous Estimation of Simultaneous Equations," Econometrica, 30 (1), 54-78.

Zins, Andreas H. (2001), "Relative Attitudes and Commitment in Customer Loyalty Models," International Journal of Service Industry Management, 12 (3), 269-94. 


\section{This article has been cited by:}

1. IpKin Anthony Wong. 2012. Exploring customer equity and the role of service experience in the casino service encounter. International Journal of Hospitality Management . [CrossRef]

2. Heiner Evanschitzky, Arun Sharma, Catja Prykop. 2012. The role of the sales employee in securing customer satisfaction. European Journal of Marketing 46:3/4, 489-508. [CrossRef]

3. Kyung Hoon Kim, Eunju Ko, Bing Xu, Yoosunn Han. 2011. Increasing customer equity of luxury fashion brands through nurturing consumer attitude. Journal of Business Research . [CrossRef]

4. Cleo Schmitt Silveira, Marta Olivia Rovedder de Oliveira, Fernando Bins Luce. 2011. Customer equity and market value: Two methods, same results?. Journal of Business Research . [CrossRef]

5. Angella J. Kim, Eunju Ko. 2011. Do social media marketing activities enhance customer equity? An empirical study of luxury fashion brand. Journal of Business Research . [CrossRef]

6. Ching-Fu Chen, Odonchimeg Myagmarsuren. 2011. Brand equity, relationship quality, relationship value, and customer loyalty: Evidence from the telecommunications services. Total Quality Management \& Business Excellence 1-18. [CrossRef]

7. Abhishek Dwivedi, Bill Merrilees. 2011. The impact of brand extensions on parent brand relationship equity. Journal of Brand Management . [CrossRef]

8. Heiner Evanschitzky, B. Ramaseshan, David M. Woisetschläger, Verena Richelsen, Markus Blut, Christof Backhaus. 2011. Consequences of customer loyalty to the loyalty program and to the company. Journal of the Academy of Marketing Science . [CrossRef]

9. Neale Martin, Kyle Morich. 2011. Unconscious mental processes in consumer choice: Toward a new model of consumer behavior. Journal of Brand Management 18:7, 483-505. [CrossRef]

10. Christian Heumann, Marion Freudenschuss, Florian v. Wangenheim, Markus Wübben. 2011. Realisierung von CrossSelling Potenzialen durch das Management von kundeninitiierten Kontakten. Zeitschrift für Betriebswirtschaft 81:S2, 31-55. [CrossRef]

11. Jing Jiang, Ting-Jui Chou, Xiaobo Tao. 2011. The Impact of Price Discount, Product Complementarity and Relational Investment on Customer Loyalty: Empirical Evidence from China's Telecommunications Industry. Asian Journal of Marketing 5:1, 1-16. [CrossRef]

12. Mari Juntunen, Jouni Juntunen, Jari Juga. 2011. Corporate brand equity and loyalty in B2B markets: A study among logistics service purchasers. Journal of Brand Management 18:4-5, 300-311. [CrossRef]

13. Masayuki Yoshida. 2011. Sport Consumer Behavior. Japanese Journal of Sport Management 3:1, 5-21. [CrossRef]

14. Son K. Lam, , Michael Ahearne, , Ye Hu, , Niels Schillewaert. 2010. Resistance to Brand Switching When a Radically New Brand Is Introduced: A Social Identity Theory Perspective. Journal of Marketing 74:6, 128-146. [Abstract] [PDF] [PDF Plus]

15. Christian Homburg, Andreas Fürst, Jana-Kristin Prigge. 2010. A customer perspective on product eliminations: how the removal of products affects customers and business relationships. Journal of the Academy of Marketing Science 38:5, 531-549. [CrossRef]

16. Kyung Hoon Kim, Seong-Yeon Park, Seunghee Lee, Dee K. Knight, Bing Xu, Byung Joo Jeon, Hak Il Moon. 2010. Examining the Relationships among Attitude toward Luxury Brands, Customer Equity, and Customer Lifetime Value in a Korean Context. Journal of Global Academy of Marketing Science 20:1, 27-34. [CrossRef]

17. Mark S. Rosenbaum, IpKin Anthony Wong. 2010. Value equity in event planning: a case study of Macau. Marketing Intelligence \& Planning 28:4, 403-417. [CrossRef]

18. Carl Marcus Wallenburg, David L. Cahill, Thomas J. Goldsby, A. Michael Knemeyer. 2010. Logistics outsourcing performance and loyalty behavior: Comparisons between Germany and the United States. International Journal of Physical Distribution \& Logistics Management 40:7, 579-602. [CrossRef]

19. Rei Saito, Munehiko Harada, Morikazu Hirose. 2010. The Scale Development for Experiential Value Scale for Sport Consumption (EVSSC) and Fan Segmentation in J-League Team. Japanese Journal of Sport Management 2:1, 3-17. [CrossRef]

20. Michael McCrary. 2009. Enhanced customer targeting with multi-stage models: Predicting customer sales and profit in the retail industry. Journal of Targeting, Measurement and Analysis for Marketing 17:4, 273-295. [CrossRef]

21. Wendy Wood, David T. Neal. 2009. The habitual consumer. Journal of Consumer Psychology 19:4, 579-592. [CrossRef]

22. Christian Homburg, , Viviana V. Steiner, , Dirk Totzek. 2009. Managing Dynamics in a Customer Portfolio. Journal of Marketing 73:5, 70-89. [Abstract] [PDF] [PDF Plus] 
23. Eli Jones, Keith A. Richards, Diane Halstead, Frank Q. Fu. 2009. Developing a strategic framework of key account performance. Journal of Strategic Marketing 17:3-4, 221-235. [CrossRef]

24. J. Joško Brakus, , Bernd H. Schmitt, , Lia Zarantonello. 2009. Brand Experience: What Is It? How Is It Measured? Does It Affect Loyalty?. Journal of Marketing 73:3, 52-68. [Abstract] [PDF] [PDF Plus]

25. CARL MARCUS WALLENBURG. 2009. INNOVATION IN LOGISTICS OUTSOURCING RELATIONSHIPS: PROACTIVE IMPROVEMENT BY LOGISTICS SERVICE PROVIDERS AS A DRIVER OF CUSTOMER LOYALTY. Journal of Supply Chain Management 45:2, 75-93. [CrossRef]

26. Eunju Ko, Kyung Hoon Kim, Sook Hyun Kim, Guofeng Li, Peng Zou, Hao Zhang. 2009. The Relationship among Country of Origin, Brand Equity and Brand Loyalty: Comparison among USA, China and Korea. Journal of Global Academy of Marketing Science 19:1, 47-58. [CrossRef]

27. Khanyapuss Punjaisri, Alan Wilson, Heiner Evanschitzky. 2009. Internal branding to influence employees' brand promise delivery: a case study in Thailand. Journal of Service Management 20:5, 561-579. [CrossRef] 